\title{
Porovnání aktuálních metodik identifikace funkčních a anaerobních prahů na bicyklovém ergometru u triatlonistů
}

\section{Comparison of current methodics for functional and anaerobic threshold identification on a bicycle ergometer by triathletes}

\author{
Lenka Kovářová, Martin Berka, David Pánek \\ Fakulta tělesné výchovy a sportu Univerzity Karlovy v Praze
}

\begin{abstract}
Abstrakt
Cílem práce bylo porovnat aktuálně využivané metodiky identifikace funkčních a anaerobních prahů prováděných na bicyklovém ergometru u triatlonistů. Výzkumný soubor tvořili výkonnostní triatlonisté (muži), pravidelní účastníci českého poháru v triatlonu ( $n=10$, věk 35,89 7,94 roku, tělesná výška $181,83 \pm 6,52 \mathrm{~cm}$, tělesná hmotnost 80,65 $\pm 6,53 \mathrm{~kg}$ ). V rámci studie jsme porovnávali metodiku hodnocení pomocí laktátové křivky, pomocí respiračních parametrů, teoretickým výpočtem, motorickým testem a Conconi test. Pro statistické zpracování dat jsme použili metodu analýzy rozptylu s opakovaným měřením, pro hodnocení významnosti rozdílů mezi jednotlivými testy pak metodu párového porovnání (Bonferroni test). Hodnocené metodiky vykazují statisticky významné rozdily $(p=0,000)$.

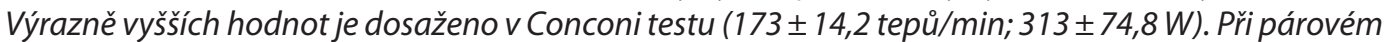
porovnání jednotlivých metodik nacházíme rozdíly mezi laktátovým a Conconi testem $v$ hodnotách $S F(p=0,037)$ stejně jako rozdil SF mezi laktátovým testem a teoretickým výpočtem $(p=0,039)$. Nejvíce statistických odchylek prí hodnocení dosažených wattů nacházíme opět v souvislosti s Conconi testem (time trial: $p=0,039$; laktátový test: $p=0,013$; spiroergometrie: $p=0,041$ ).
\end{abstract}

\begin{abstract}
The aim of the study was to compare the currently methodics for identification functional and anaerobic thresholds on a bicycle ergometer by triathletes. The sample included triathletes (men), regular participants in the Czech triathlon cup ( $n=10$, age $35.89 \pm 7.94$ years, body height $181.83 \pm 6.52 \mathrm{~cm}$, weight $80.65 \pm 6.53 \mathrm{~kg}$ ). In the study, we compared the evaluation methodics using lactate curve, respiratory parameters, theoretical calculation, motor test and Conconi test. For statistical data processing we used the Repeated Measures, for evaluating the significance of differences between each test method then pairwise comparation (Bonferroni test). Results showed statistically significant differences $(p=0.000)$. Significantly higher values are reached in Conconi test $\left(173 \pm 14.2\right.$ beats. min $^{-1}, 313 \pm 74.8$ $W)$. In pairwise comparison of methodics are differences between lactate and Conconi test in HR values $(p=0.037)$ as well as the difference between HR lactate test and theoretical calculation $(p=0.039)$. Most statistical variations in the watts evaluation is found again in connection with Conconi test (time trial: $p=0.039$; lactate test: $p=0.013$; spiroergometry: $p=0.041$ ).
\end{abstract}

Klíčová slova: diagnostika, vytrvalost, triatlon, trénink.

Key words: diagnostics, endurance, triathlon, training.

Tento článek vznikl za podpory GAČR 13-07776P a v rámci programu rozvoje vědního oboru UK FTVS č. 39 Společenskovědní aspekty zkoumání lidského pohybu. 


\section{ÚVOD}

Identifikace anaerobního prahu (ANP) je jak nezbytným prediktorem výkonu při výběru talentů, tak jeden $\mathrm{z}$ nejdůležitějších nástrojů při řízení intenzity zatížení v tréninku. Costill (1970) charakterizuje ANP jako maximální intenzitu konstantního zatížení, při které je ještě v rovnováze tvorba a utilizace krevního laktátu (LA). Tento práh porušení dynamické rovnováhy a nezkompenzovaného vzestupu koncentrace LA v krvi lze zjištovat v zásadě dvěma způsoby: invazivně, na základě změn koncentrace laktátu v krvi při stoupajícím zatížení (Bunc, Šprýnarová, Heller, \& Zdanowicz, 1984; Brooks, 1985), nebo neinvazivně na základě změn respiračních parametrů nebo srdeční frekvence $\mathrm{v}$ závislosti na stoupajícím zatížení nebo spotřebě kyslíku, popřípadě jejich vzájemných změn při stoupajícím zatížení, nebo využitím nelineárních změn integrovaného elektromyogramu, případně využitím vhodně zvoleného motorického testu (Bachl, Reiterer, Prokop, \& Czitober, 1978; Bunc, 1989).

Rozhodující roli při všech př́istupech stanovení ANP má způsob zatěžování tj. intenzita a doba trvání jednotlivých zatížení. Významná je i použitá metoda stanovení ANP a parametry, které byly pro stanovení vybrány. Mluvíme proto o tzv. laktátovém nebo např. ventilačním prahu.

Ve sportovní praxi se v minulosti používalo nejčastěji stanovení ANP na hladině LA 4 mmol. l $^{-1}$, v současnosti převládá metodika stanovení individuálního anaerobního prahu. Úroveň anaerobního prahu je dle Grasgrubera a Cacka (2008) ovlivněna několika faktory: vysokým podílem pomalých vláken, svalovým prokrvením, počtem a velikostí mitochondrií, aktivitou oxidačních enzymů v mitochondriích a schopností distribuovat pracovní výkon na větší množství svalstva. Pro dlouhodobý vytrvalostní výkon je důležitější než aktuální rychlost pohybu na ANP doba, po kterou je sportovec schopen se na uvedené intenzitě pohybovat, tedy jeho kapacita na úrovni ANP. Tento ukazatel je důležitou informací o stavu trénovanosti sportovce. Schopnost dlouhodobě vykonávat pohyb na takto vysoké intenzitě je pro vytrvalostní trénink klíčová a její rozvoj zásadní pro zlepšení výkonu sportovce.

Posuzováním úrovně ANP jako jednoho z limitujících ukazatelů vytrvalostního výkonu na příkladu triatlonu se zabývala v minulosti již řada výzkumů (např. O' Toole, Douglas, \& Hiller, 1989; Schneider, Lacroix, Atkinson, Troped, \& Pollack, 1990; Zhou, Robson, King, \& Davie, 1997; Hue, Le Gallais, Chollet, Boussana, \& Prefaut, 2000; Schabort, Killian, St Clair Gibson, Hawley, \& Noakes 2000; Bentley, Millet, Vleck, \& Mcnaugthon, 2002; Millet, Dreano, \& Bentley, 2003, Van Schuylenbergh, Vanden, \& Hespel, 2004), šlo však spíše o výzkumy analyzující vztah mezi výkonem na ANP a výkonem v závodě, popř. výkonem na ANP a vybraným motorickým testem realizovaným $\mathrm{v}$ terénu nebo laboratoři.

V současné době se ve sportovním prostředí použivá několik základní metodik identifikace anaerobního, resp. funkčního prahu. Kromě metodik vycházejících z respiračních parametrů a koncentrace LA v krvi, jde o tzv. Conconi test (Conconi, Ferrari, Ziglio, Droghetti, \& Codeca, 1982). V tomto př́ipadě se však nejedná o anaerobní práh, ale o tzv. práh cirkulační.

Ve výkonnostní a vrcholové cyklistice se nově používá motorický test - časovka v délce trvání 20 minut. Jako hodnota dosaženého prahového výkonu je uvažováno $95 \% \mathrm{z}$ dosaženého průměrného maximálního výkonu (Allen, 2002). Zde v pravém slova smyslu také nejde a práh anaerobní (nehledáme bod zlomu), ale o stanovení funkčního prahového výkonu (FPV).

V nesportující populaci je stále ještě velmi populární stanovení ANP pomocí výpočtu - odhadu z hodnot maximální SF; srdeční frekvence na úrovni anaerobního prahu u vytrvalostně trénovaných sportovců leží v pásmu 88-93\% maximální SF. V praxi se proto používá pro stanovení SF na úrovni anaerobního prahu hodnota 90 \% maximální SF (Formánek, Horčic, 2004).

V současné době je tedy pro identifikaci prahových hodnot možno použit několik velmi odlišných metodik. Otázkou zůstává, zda se jejich výsledky budou statisticky lišit, popř. u kterých $\mathrm{z}$ nich. 
Cílem práce je tedy porovnat $\mathrm{v}$ praxi aktuálně nejčastěji používané nepřímé metody stanovení funkčních a anaerobních prahů prováděných na bicyklovém ergometru, který se v diagnostice vytrvalostních sportovců využívá nejčastěji.

\section{METODIKA}

\section{Výzkumný soubor}

Výzkumný soubor tvořili výkonnostní triatlonisté (muži), pravidelní účastníci českého poháru v triatlonu ( $\mathrm{n}=10$, věk $35,89 \pm 7,94$, tělesná výška $181,83 \pm 6,52 \mathrm{~cm}$, tělesná hmotnost $80,65 \pm 6,53 \mathrm{~kg})$.

\section{Výzkumné nástroje}

V rámci studie jsme ověřovali tyto metodiky:

1. Spiroergometrie, metoda V-slope

Test byl proveden do vita maxima. Intenzita zatížení (výkon) v prvním úseku byla stanovena výpočtem.

Výkon $(\mathrm{W})=$ hmotnost probanda $(\mathrm{kg}) * 2$

Každou započatou minutu bylo zatížení navýšeno o $20 \mathrm{~W}$. Průběžně byl registrován nárůst srdeční frekvence i ventilačně-respiračních ukazatelů (minutové ventilace, dechové frekvence, spotřeba kyslíku, poměr respirační výměny RER). Pro stanovení ANP jsme použili V-slope metodu, která vychází ze vztahu $\mathrm{VCO}_{2}$ a $\mathrm{VO}_{2}$. V rámci studie jsme využili ergometr Excalibur Sport (Lode) a analyzátor plynů Metalyzer (Cortex). Povodní naměřené spirometrické hodnoty dech po dechu byly zprůměrovány $\mathrm{v}$ dvaceti sekundových intervalech.

2. Laktátový stupňovaný test

Intenzita zatížení v prvním úseku byla stanovena výpočtem.

Výkon $(\mathrm{W})=$ hmotnost probanda $(\mathrm{kg}) * 2$

Délka každého úseku byla 4 minuty, intenzita zatížení se stupňovala o $30 \mathrm{~W}$ na počátku dalšího započatého úseku. Krev pro stanovení hodnoty LA byla odebírána z ušního lalůčku na konci každého absolvovaného úseku, těsně před tím byla odečtena aktuální SF. Počet úseků se pohyboval na základě výkonnosti probandů mezi 5-7. Pro diagnostiku ANP jsme využili metodu Free Freiburg (Simon) treshold, tj. stanovení ANP v bodu strmého nárůstu laktátu. Bod byl stanoven jako průměrná hodnota laktátu prvních úseků, jejichž vzájemný rozdíl není vyšší než $0,5 \mathrm{mmol} / 1,+1,5 \mathrm{mmol} / 1$.

3. Conconi test

Test byl proveden paralelně se spieroergometrickým stupňovaným testem. Po celou dobu testu byla zaznamenávána SF. Záznam srdeční frekvence byl následně zpracován pomocí softwaru Polar pro identifikaci cirkulačního prahu pomocí Conconi testu. Práh byl stanoven v místě porušení linearity nárůstu SF během testu.

4. Time trail test - stanovení funkčního prahového výkonu (FPV)

Méně známý test používaný především cyklisty. Zadáním testu je absolvovat dvaceti minutový úsek s co nejvyšším průměrným výkonem $(\mathrm{W})$. Jako hodnota dosaženého funkčního prahového výkonu je pak bráno $95 \% \mathrm{z}$ naměřených průměrných hodnot. $\mathrm{SF}_{\mathrm{FTP}}$ je stanovena rovněž na $95 \%$ z naměřených průměrných hodnot (Allen, 2002).

5. Stanovení ANP teoretickým výpočtem

Pro teoretický výpočet jsme použili následující vzorec (Formánek, Horčic, 2004):

SF anp $=0,9 \times(220-$ věk probanda $)$ 
Každému testu předcházelo standardní rozcvičení sportovce ( 5 min) při intenzitě [3] a následně (5 min) při intenzitě [4].

Výkon $(\mathrm{W})=$ hmotnost probanda $(\mathrm{kg}) * 1,5$

Výkon $(\mathrm{W})=$ hmotnost probanda $(\mathrm{kg}) * 2$

Po rozcvičení následovala pauza několik minut. Testování metodik proběhlo vždy s týdenním odstupem mezi jednotlivými měřeními. Interval mezi testováním byl zvolen jako doba, během které dojde k úplné regeneraci organismu, zároveň však nedojde k výkonnostním změnám probandů, způsobených např. tréninkem. Testování bylo provedeno na přelomu ledna a února, tedy v době, kdy není cyklistika v tréninku př́liš akcentována, čímž bylo toto riziko rovněž sníženo. U každého testu jsme posuzovali jak prahovou hodnotu SF, dále pak výkon odpovídající této intenzitě. Pořadí testů každého probanda bylo randomizováno. Výzkum byl schválen Etickou komisí UK FTVS pod číslem 0198/2013.s

\section{Statistické zpracování dat}

Vzhledem k charakteristice dat jsme pro statistické zpracování použili metodu analýzy rozptylu s opakováním měření, pro hodnocení významnosti rozdílů mezi jednotlivými testy pak metodu post hoc testu (Bonferroni test). Pro analýzu dat jsme použili software IBM SPSS Statistics 22. Statistickou významnost jsme stanovili na hladině 0,05 .

\section{VÝSLEDKY}

V Tabulce 1 uvádíme základní charakteristiky hodnocených parametrů (průměr, SD) u jednotlivých metodik.

Tab. 1: Základní charakteristika analyzovaných parametrů (SF, W) u jednotlivých metodik

\begin{tabular}{|l|c|c|c|c|}
\hline & \multicolumn{2}{|c|}{ SF } & \multicolumn{2}{c|}{ W } \\
\hline & průměr & SD & průměr & SD \\
\hline Time trial & 162 & 11,4 & 234 & 26,8 \\
\hline Laktátový test & 157 & 6,4 & 235 & 27,0 \\
\hline Spiroergometrický test & 156 & 11,0 & 233 & 26,5 \\
\hline Conconi test & 173 & 14,2 & 313 & 74,8 \\
\hline Teoretický výpočet & 165 & 6,9 & NM & NM \\
\hline
\end{tabular}

Z výsledků je zřejmé, že výrazně vyšších hodnot (jak SF, tak W) je dosaženo v Conconi testu. V tomto testu je zároveň nejvyšši SD, což ukazuje na velké variační rozpětí dosažených výsledků jednotlivých probandů. Tabulka 2 pak dokazuje i statisticky významné rozdíly mezi výsledky v jednotlivých testech a potvrzuje, že všechny metodiky nelze považovat za zaměnitelné.

Tab. 2: Testy meziskupinového efektu

\begin{tabular}{|l|c|c|c|c|c|c|}
\hline Source: & Type III Sum of Squares & df & Mean Square & F & Sig. & Partial Eta Squared \\
\hline SF & & & & & & \\
Intercept & 1321612,820 & 1 & 1321612,820 & 5734,563 &, 000 &, 998 \\
Error & 2074,180 & 9 & 230,464 & & & \\
\hline W & & & & & & \\
Intercept & 2575562,500 & 1 & 2575562,500 & 658,609 &, 000 &, 987 \\
Error & 35195,500 & 9 & 3910,611 & & & \\
\hline
\end{tabular}


V Tabulce 3 nalezneme párové srovnání výsledků SF u jednotlivých metodik hodnocených pomocí Bonferroniho testu.

Tab. 3: Výsledky párového porovnání hodnot SF mezi jednotlivými metodikami

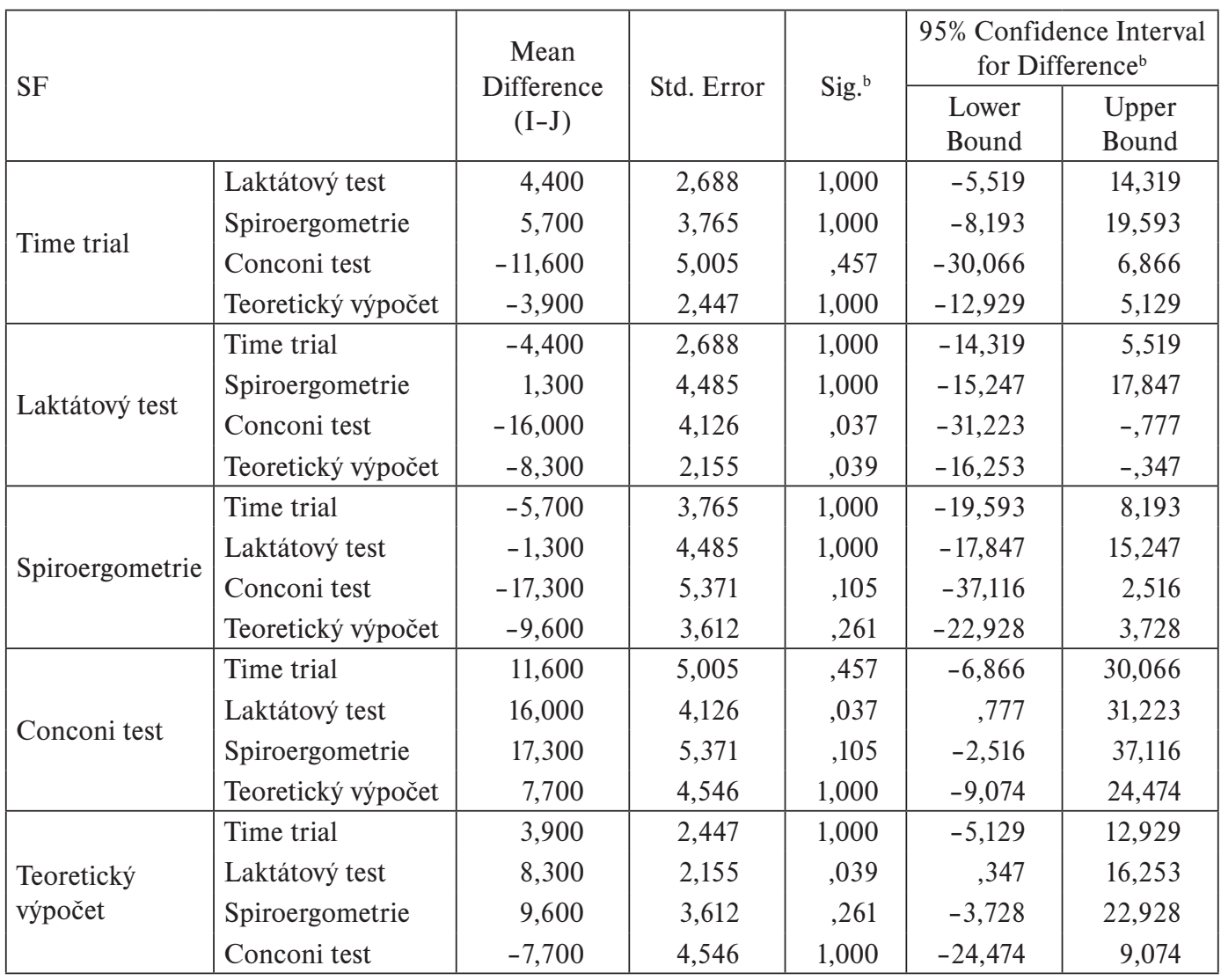

b. Adjustovaná vícenásobná komparace: Bonferroni

Z výsledků vidíme statisticky významně odlišné hodnoty mezi testem laktátovým a Conconi $(\mathrm{p}=0,037)$ a stanovením SF pomocí teoretického výpočtu $(\mathrm{p}=0,039)$. Mezi hodnotami SF dosaženými u ostatních metodik se statisticky významné rozdíly neprokázaly.

Pokud budeme hodnotit výsledky dosažených prahových hodnot wattů $\mathrm{v}$ jednotlivých metodikách (Tabulka 4), pak nacházíme opět nejvíce statistických odchylek v souvislosti s Conconi testem (time trial: $p=0,039$; laktátový test: $p=0,013$; spiroergometrie: $p=0,041$ ), naopak mezi ostatními testy prokázané rozdíly nenacházíme. 
Tab. 4: Výsledky párového porovnání prahových hodnot wattů mezi jednotlivými metodikami

\begin{tabular}{|c|c|c|c|c|c|c|}
\hline \multirow{2}{*}{\multicolumn{2}{|c|}{ SF }} & \multirow{3}{*}{$\begin{array}{c}\text { Mean } \\
\text { Difference } \\
(\mathrm{I}-\mathrm{J})\end{array}$} & \multirow{3}{*}{$\begin{array}{c}\text { Std. Error } \\
8,555\end{array}$} & \multirow{3}{*}{$\begin{array}{l}\text { Sig. }{ }^{\text {b }} \\
1,000\end{array}$} & \multicolumn{2}{|c|}{$\begin{array}{l}\text { 95\% Confidence Interval } \\
\text { for Difference }\end{array}$} \\
\hline & & & & & \multirow{2}{*}{$\begin{array}{c}\begin{array}{c}\text { Lower } \\
\text { Bound }\end{array} \\
-29,582\end{array}$} & \multirow{2}{*}{$\begin{array}{c}\text { Upper } \\
\text { Bound } \\
27,982\end{array}$} \\
\hline \multirow{3}{*}{ Time trial } & Laktátový test & & & & & \\
\hline & Spiroergometrie & 2,100 & 7,508 & 1,000 & $-23,157$ & 27,357 \\
\hline & Conconi test & $-77,900$ & 22,107 & 039 & $-152,271$ & $-3,529$ \\
\hline \multirow{3}{*}{ Laktátový test } & Time trial & 800 & 8,555 & 1,000 & $-27,982$ & 29,582 \\
\hline & Spiroergometrie & 2,900 & 7,879 & 1,000 & $-23,606$ & 29,406 \\
\hline & Conconi test & $-77,100$ & 18,067 & 013 & $-137,880$ & $-16,320$ \\
\hline \multirow{3}{*}{ Spiroergometrie } & Time trial & $-2,100$ & 7,508 & 1,000 & $-27,357$ & 23,157 \\
\hline & Laktátový test & $-2,900$ & 7,879 & 1,000 & $-29,406$ & 23,606 \\
\hline & Conconi test & $-80,000$ & 22,913 & ,041 & $-157,084$ & $-2,916$ \\
\hline \multirow{3}{*}{ Conconi test } & Time trial & 77,900 & 22,107 & ,039 & 3,529 & 152,271 \\
\hline & Laktátový test & 77,100 & 18,067 & 013 & 16,320 & 137,880 \\
\hline & Spiroergometrie & 80,000 & 22,913 & 041 & 2,916 & 157,084 \\
\hline
\end{tabular}

b. Adjustovaná mnohonásobná komparace: Bonferroni

\section{DISKUZE}

Conconi testem jsme dospěli podobně jako např. Bourgois, a Vrijens (1998) k rozdílným výsledkům. Menší, ale významné, rozdíly dosáhly i hodnoty stanovené teoretickým výpočtem. Nutno poznamenat, že jednoduchá metodika (výpočet), vychází vždy z průměrné populace, ale výzkumný soubor tvořili sportovci vytrvalci. Nicméně řada hobby sportovců, kteří se i často účastní dnes populárních vytrvalostních závodů (běhy, cyklistika, běžecké lyžování a triatlon), se $\mathrm{v}$ tréninku takovými údaji řídí.

Možné př́iciny odlišných výsledků Conconi testu spatřujeme v tom, že tento test pracuje pouze se srdeční frekvencí a délka jednotlivých úseků je velmi krátká. Srdeční frekvence reaguje na zvýšení vnějšího zatížení se zpožděním, kdy nedochází k plné adaptaci na zatížení (Neumann, Pfützner, \& Hottenrott, 2000). Pokud tedy zatížení neustále roste v krátkých časových intervalech, organismus nestihne dosáhnout tzv.steady state stavu, tedy stavu, kdy SF odpovídá vnějšímu zatížení. Než teprve SF zareaguje na předchozí zátěž a dosáhne např. hodnoty anaerobního prahu, vnější zatižení již opět naroste. $Z$ tohoto důvodu jsou výsledky testů změřené pomocí Conconi testu nadhodnocené.

Metodika teoretického výpočtu nepracuje s aktuální výkonností ani typem tréninku, který proband soustavně podstupuje. Vlivem adaptace na vytrvalostní zátěž dochází k mnoha fyziologickým jevům, jedním z nich je snížení jak klidové, tak submaximální SF (Máček, 1999). Oproti nesportující populaci budou tedy hodnoty vytrvalců nižší a tato metodika bude vykazovat nadhodnocených výsledků, což naše studie dokazuje.

Srovnatelnost a tím i zaměnitelnost metodiky hodnocení pomocí laktátové křivky a spiroergometrického testu jsme předpokládali. Pozitivním zjištěním je fakt, že srovnatelné výsledky nacházíme i u motorického testu - časovky na 20 minut. Velkou výhodnou tohoto testu je nízká finanční, materiální i odborná náročnost. Podmínkou není ani specializované pracoviště vybavené pro potřeby invazivních metod (odběr krve a jeho analýza), tak neinvazivních, ale finančně náročných (analyzátor plynů pro funkční zátěžovou diagnostiku). Problém jsme spíše zaznamenali při samotné realizaci testu. Výkonnostně horší probandi měli problém s odhadem optimální intenzity zatížení, která může mít dopad na celkový výkon. Je proto vhodné test předem vyzkoušet, byt 
např. v kratším časovém režimu (Allen, 20002). Na druhou stranu lze konstatovat, že zařízení, které umožňuje v cyklistice měření výkonu (wattmetr), používají zatím spíše sportovci s vysokou výkonností.

\section{ZÁVĚR}

Z výsledků našeho výzkumu vyplývá, že hodnocené metodiky nedosahují statisticky shodných výsledků. Výrazně vy̌šśích hodnot (jak SF, tak W) je dosaženo v Conconi testu (173 $\pm 14,2$ tepů/min; $313 \pm 74,8 \mathrm{~W})$.

Při párovém porovnání jednotlivých metodik nacházíme rozdíly v hodnotách SF mezi testem laktátovým a Conconi $(\mathrm{p}=0,037)$ a laktátovým a stanovením SF pomocí teoretického výpočtu $(\mathrm{p}=0,039)$.

Při hodnocení parametru dosažených prahových hodnot wattů nacházíme opět nejvíce statistických odchylek v souvislosti s Conconi testem (time trial: $p=0,039$; laktátový test: $p=0,013$; spiroergometrie: $\mathrm{p}=0,041$ ), naopak mezi ostatními testy prokázané rozdíly nenacházíme.

Conconi test pro potřeby vytrvalostních sportovců nedoporučujeme, stejně tak, jak metodu stanovení ANP pomocí teoretického výpočtu.

\section{Literatura}

Allen H., \& Coggan A. (2005). Training and rating with a power meter. VeloPress.

Bachl, N., Reiterer, W., Prokop, L., \& Czitober, H. (1978). Bestimmungsmetoden der anaeroben Schwelle. Österreich Journal of Sportmedicine 8, 9-12.

Bentley, D. J., Millet, G. P., Vleck, V. E., \& McNaugthon, L. R. (2002). Specific aspects of contemporary triathlon: implications for physiological analysis and performance. Sports Medicine 32 (6), 345-359.

Bourgois J. \& Vrijens J. (1998). The Conconi test: a controversial concept for the determination of the anaerobic threshold in young rowers. International Journal of Sports Medicine 19, (8), 553-9.

Brooks, G. A. (1985). Anaerobic threshold: review of the concept and directions for future research. Medicine and Science in Sports and Exercise 17, 22-31.

Bunc, V. (1989). Biokybernetický prístup k hodnocení reakce organismu na tělesné zatížení. Praha : Univerzita Karlova.

Bunc, V., Šprýnarová, Š., Heller, J., \& Zdanowicz, R. (1984). Možnosti využití anaerobního prahu ve fyziologii práce. II. Metody stanovení araerobného prahu. Pracovni lékařství 36, 127-133.

Conconi, F; Ferrari, M; Ziglio, P. G.; Droghetti P., \& Codeca L. (1982). Determination of the anaerobic threshold by a noninvasive field test in runners. Journal of applied physiology: respiratory, environmental and exercise physiology 52, (4), 869-73

Costill, D. L. (1970). Metabolic responses during distance running. Journal of Applied Physiology 28 (3), 151-155.

Formánek, J., Horčic, J. (2003). Triatlon. Praha: Olympia, a. s.

Grasgruber, P., \& Cacek, J. (2008). Sportovní geny. Brno: Computer Press a.s.

Hue, O., Le Gallais, D., Chollet, D., Boussana, A., \& Préfaut, C. (2000). Ventilatory treshold and maxinal oxygen uptake in present triathletes. Canadian Journal of Applied Physiology 25, 102-113.

Máček, M. (1999). Reakce a adaptace na tělesnou zátěž. In Kučera, M., \& Dylevský, I. (Ed.), Sportovnímedicína. Praha: Grada.

Millet, G. P., Dreano, P., \& Bentley, D. J. (2003). Physiological characteristics of elite short- and long-distance triathletes. European Journal of Applied Physiology 88, 427-30.

Neumann, G., Pfützner, A., \& Hottenrott, K. (2000). Alles unter Kontrolle. Verlag: Meyer \& Meyer Sport.

O'Toole, M. L., Douglas, P. S., \& Hiller, W. B. (1989). Lactat, oxygen uptake and cycling performance in triathletes. International Journal of Sports Medicine 10,413-418.

Schabort, E. J., Killian, S. C., St Clair Gibson, A., Hawley, J. A., \& Noakes, T. D. (2000). Prediction of triathlon race time from laboratory testing in national triathletes. Medicine and Science in Sports and Exercise 32, 844-849.

Schneider, D. A., Lacroix, K. A., Atkinson, G. R., Troped, P. J., \& Pollack, J. (1990). Ventilatory threshold and maximal oxygen uptake during cycling and runnig in traithletes. Medicine and Science in Sports and Exercise 22, 257-264.

Van Schuylenbergh, R., Vanden Eynde, B., \& Hespel, P. (2004). Prediction of sprint triathlon performance from laboratory tests. European Journal of Applied Physiology 91, 94-99.

Zhou, S., Robson, J., King, M. J., \& Davie, A. J. (1997). Correlations between short-course triathlon performance and physiological variables determined in laboratory cycle and treadmill tests. Journal of Sports Medicine and Physical Fitness 37, 122-130. 